\title{
Curriculum matrix development for a hepato-pancreato-biliary robotic surgery fellowship
}

\author{
Maria Baimas-George, MD, MPH \\ Michael Watson, MD \\ John Martinie, MD \\ Dionisios Vrochides, MD, PhD
}

Accepted February 4, 2021

\section{Correspondence to: \\ D. Vrochides \\ Division of Hepatobiliary and Pancreas Surgery \\ Department of Surgery \\ Carolinas Medical Center \\ 1025 Morehead Medical Drive, Suite 600 \\ Charlotte, North Carolina 28204 \\ Dionisios.Vrochides@atriumhealth.org}

Cite as: Can J Surg 2021 December 8; 64(6). doi: $10.1503 /$ cjs. 002620

\section{SUMmARY}

Robotic surgery is being increasingly used for complex benign and malignant hepato-pancreato-biliary (HPB) cases. As use of robotics increases, fellowships to excel in complex robotic procedures will be sought after. With this dedicated training, attending surgeon positions can be obtained that can incorporate and teach this skill set. Unfortunately, there are no evidence-based approaches for constructing a curriculum for an HPB robotic surgery fellowship. This paper describes a technique to develop a structured curriculum to ensure competence and fulfil the learning and practice needs for robotic HPB fellows.

T he robotic platform in hepato-pancreato-biliary (HPB) disease is starting to gain popularity owing to the advantages it technically can offer over conventional and open techniques. Robotic surgery overcomes laparoscopic limitations through optical magnification, 3-D depth perception, augmented instrument articulation, and greater precision with suture targeting. ${ }^{1}$ These benefits have brought robotic surgery to the forefront as an attractive and, more importantly, inclusive opportunity for a minimally invasive approach to complex and benign HPB disease. With studies correlating technical performance and surgeon volume with postoperative outcomes, the importance of effective training is paramount. ${ }^{2,3}$ Unfortunately, even new graduates are lacking comfort and skill in the robotic arena owing to considerable disparities across education and technical experience of robotic exposure during training. While there have been improvements over the last decade in regards to resident participation in robotic cases, formal curricula remain variable and lacking. ${ }^{4,5}$ And, unfortunately, these curricula often limit participation to mainly observation, resulting in inexperienced graduates without the appropriate skill set to operate safely while unaccompanied. ${ }^{6}$ As a consequence, skill development in this area among attending surgeons depends on the needs of the professional community and surgical societies. As such, a role for robotic fellowships has emerged for comprehensive and formalized training. With no current evidence-based approaches for constructing a curriculum for an HPB robotic surgery fellowship, we describe here our technique in creating a structured curriculum at the Carolinas Medical Center, Atrium Health.

Our HPB robotic surgery fellowship is a 12 -month commitment that lies between a postgraduate education level and continuing professional development. As such, the curriculum is customized to meet individual needs and is designed to ensure fellows achieve a minimum level of competence, professionalism and patient safety ${ }^{7}$ (Table 1). Thus, there are 2 proposed pathways: pure clinical, and clinical and research.

The pathway model addresses content overload and allows each to concentrate on modules or competencies that may be more important in future practice. The essential technical competencies are incorporated 


\begin{tabular}{|c|c|}
\hline Title & Hepato-pancreato-biliary (HPB) robotic surgery fellowship \\
\hline \multirow[t]{2}{*}{ Target audience } & $\begin{array}{l}\text { The HPB robotic surgery fellowship is offered to physicians who completed an official training in general surgery and an AHPBA-accredited } \\
\text { HPB surgery fellowship. Furthermore, they should be board-eligible or -certified either by the American Board of Surgery (ABS) or the Royal } \\
\text { College of Surgeons (RCS) or the European Board of Surgery (EBS). }\end{array}$ \\
\hline & This is a 12-month fellowship. One fellow per year will be trained. \\
\hline \multirow{4}{*}{$\begin{array}{l}\text { Summary of the } \\
\text { curriculum } \\
\text { rationale }\end{array}$} & $\begin{array}{l}\text { For "customization" purposes, at the beginning of this } 12 \text {-month HPB robotic surgery fellowship, fellows should chose which of the following } \\
\text { pathways to pursue: }\end{array}$ \\
\hline & 1) Pure clinical \\
\hline & 2) Clinical and research \\
\hline & The curriculum structure and content for each fellow is built according to the chosen pathway. \\
\hline \multirow{8}{*}{$\begin{array}{l}\text { Aim of the } \\
\text { curriculum }\end{array}$} & At the conclusion of the HPB robotic surgery fellowship, the fellow will be able to: \\
\hline & 1) Perform robotically HPB-relevant operative procedures \\
\hline & 2) Provide state-of-the-art postoperative care for patients who underwent HPB robotic surgery procedures \\
\hline & 3) Counsel referring colleagues on HPB robotic surgery \\
\hline & 4) Act in a multidisciplinary environment \\
\hline & 5) Recognize and acquire emerging knowledge regarding HPB robotic surgery \\
\hline & 6) Conceive, realize, present and publish research projects regarding HPB robotic surgery \\
\hline & 7) Develop and support institutional programs related to HPB robotic surgery professional and societal policies \\
\hline \multirow[t]{15}{*}{$\begin{array}{l}\text { Structure of the } \\
\text { curriculum }\end{array}$} & $\begin{array}{l}\text { There are } 8 \text { core and } 6 \text { elective modules that each last } 4 \text { weeks }(1 \text { month). A fellow is obligated to follow the } 8 \text { core and, depending on the } \\
\text { chosen pathway, another } 4 \text { elective modules. The available modules are: }\end{array}$ \\
\hline & $\begin{array}{l}\text { 1) Introduction to HPB robotic surgery / dVS phase 1. Technology of robotic surgery (online modules and dV training centre) / dVS phase } 2 . \\
\text { Robotic skills simulator / dVS phase 3ll (core) }\end{array}$ \\
\hline & 2) Dry laboratory skills simulator / dVS phase 3I\&ll (core) \\
\hline & 3) Biliary 1, bedside and console / dVS phase 3I (core) \\
\hline & 4) Biliary 2, console / dVS phase 3II (core) \\
\hline & 5) Pancreas 1, bedside and console / dVS phase 3I (core) \\
\hline & 6) Pancreas 2, console / dVS phase 3II (core) \\
\hline & 7) Liver 1, bedside and console / dVS phase 3I (core) \\
\hline & 8) Liver 2, console / dVS phase 3II (core) \\
\hline & 9) Biliary 3, console / dVS phase 3II (elective, mandatory for the pure clinical pathway) \\
\hline & 10) Pancreas 3, console / dVS phase 3II (elective, mandatory for the pure clinical pathway) \\
\hline & 11) Liver 3, console / dVS phase 3II (elective, mandatory for the pure clinical pathway) \\
\hline & 12) HPB robotic surgery clinical research / dVS phase IV (elective, mandatory for the clinical and research pathway) \\
\hline & 13) HPB robotic surgery educational research / dVS phase IV (elective, mandatory for the clinical and research pathway) \\
\hline & 14) HPB robotic surgery authorship / dVS phase IV (elective, mandatory for the clinical and research pathway) \\
\hline \multirow[t]{2}{*}{$\begin{array}{l}\text { Informative } \\
\text { comments }\end{array}$} & $\begin{array}{l}\text { Modules } 1 \text { and } 2 \text { include online and skill simulators training, and they are delivered mainly in the Department of Surgery Research Laboratory } \\
\text { facilities. Modules } 3-11 \text { combine teaching with clinical work. They are delivered in the hospital and in the medical offices; depending on } \\
\text { caseload, bedside modules }(3,5 \text { and } 7) \text { and console modules }(4,6,8,9 \text { and } 10) \text { may run in parallel. Modules } 12-14 \text { involve database analysis } \\
\text { and utilization of skills simulators. They are delivered mainly in the Department of Surgery Research Laboratory facilities. }\end{array}$ \\
\hline & $\begin{array}{l}\text { Teachers, under the direct supervision of the program director (Dr. J. Martinie, MD, FACS), include all } 4 \text { HPB surgeons of the department, } \\
2 \text { HPB surgery fellows, medical researchers ( } 2 \text { PhD holders in experimental surgery) and various other medical faculty members (e.g., } \\
3 \text { information technology experts, } 1 \text { educationist, } 1 \text { lead medical writer). }\end{array}$ \\
\hline
\end{tabular}

into 8 core modules that are required for both pathways. The modules are based on the adult learning theory that emphasizes problem-based learning and active trainee participation. ${ }^{8}$ Over the last several decades, medical education has shifted from teaching to learning owing to this theory; however, it is not only learning theories that influence a curriculum design, especially on a postgraduate level. ${ }^{9}$ The trainee should also be able to identify and solve clinical problems in the real world with minimal to no supervision. Consequently, the medical curriculum at a postgraduate level should be problem-based and integrate knowledge, skills, and attitudes. In a word, it should be made for practice. ${ }^{10}$ Thus, each of these proposed modules follow the principles of adult learning theory and are problem-based.
The curriculum begins with 4 core modules that follow a spiral model (Table 2). ${ }^{3}$ Module 1 involves an introduction to robotics, discussing technology and equipment to allow for efficient use and appropriate troubleshooting. A robotic skill simulator is used to familiarize the trainees, and Module 2 follows with dry laboratory simulation to practise set-up basics to suturing anastomoses. The simulations are recorded to assess learning curves and areas for improvement. The next 3 modules focus on completion of simple index procedures, such as cholecystectomies, or core parts of larger complex cases while simultaneously advancing work in the dry laboratory (Figure 1). As competence increases, more complex procedures, such as pancreaticoduodenectomies and major hepatectomies, are taught in the subsequent core modules. After completion of the core 
Table 2 (part 1 of 2). The HPB robotic surgery fellowship curriculum matrix aligning intended learning outcomes, teaching and learning activities and assessments

\begin{tabular}{|c|c|c|c|c|}
\hline Module & Intended learning outcomes & $\begin{array}{l}\text { Teaching and learning } \\
\text { activities }\end{array}$ & Indicative content & Assessment \\
\hline $\begin{array}{l}\text { Introduction / } \\
\text { technology / } \\
\text { robotic skills } \\
\text { simulator }\end{array}$ & $\begin{array}{l}\text { 1. Introduction to robotic HPB surgery } \\
\text { 2. Learning the technology of the } \\
\text { robotic platform } \\
\text { 3. Improving robotic skills by } \\
\text { simulation }\end{array}$ & $\begin{array}{l}\text { 1a. Lecture } \\
\text { 1b. Video } \\
\text { 2a. Online modules } \\
\text { 2b. Hands-on course } \\
\text { 3. Robotic skills } \\
\text { simulator }\end{array}$ & $\begin{array}{l}\text { 1a. Trocar placement in robotic HPB surgery } \\
\text { 1b. Video of a robotic PPPD } \\
\text { 2a. Energy devices in robotic surgery } \\
\text { 2b. Spatial considerations in robotic surgery } \\
\text { 3. Mastering the } 10 \text { simulated robotic skills }\end{array}$ & $\begin{array}{c}\text { 1a. MCQ } \\
\text { 1b. EMQ } \\
\text { 2a. On line } d V \text { certificate } \\
\text { 2b. dv Training centre } \\
\text { certificate } \\
\text { 3. MIMIC ratings }\end{array}$ \\
\hline $\begin{array}{l}\text { Dry skills } \\
\text { laboratory }\end{array}$ & $\begin{array}{l}\text { 1. Perform docking } \\
\text { 2. Perform simple tasks (modified } \\
\text { simulation skills) } \\
\text { 3. Perform customized tasks }\end{array}$ & $\begin{array}{l}\text { 1. Demonstration } \\
\text { 2. Perform in dry } \\
\text { laboratory } \\
\text { 3. Perform in dry } \\
\text { laboratory }\end{array}$ & $\begin{array}{l}\text { 1. Xi platform docking differences } \\
\text { 2. Modified simulation skills } \\
\text { 3. Dry laboratory construction of robotic PJ }\end{array}$ & $\begin{array}{l}\text { 1. Tutor / self assess } \\
\text { 2. Video analysis } \\
\text { 3. CUSUM learning curve }\end{array}$ \\
\hline Biliary 1 & $\begin{array}{l}\text { 1. Follow up of patients after robotic } \\
\text { biliary surgery } \\
\text { 2. Perform simple robotic biliary } \\
\text { operations }\end{array}$ & $\begin{array}{l}\text { 1a. Shadow office hours } \\
\text { 1b. PBL } \\
\text { 2a. Assist in OR } \\
\text { 2b. Perform in OR } \\
\text { 3c. Simulation laboratory }\end{array}$ & $\begin{array}{l}\text { 1a. Follow-up robotic CCY } \\
\text { 1b. Planning of a proposed robotic CCY } \\
\text { 2a. Bedside in a robotic CCY } \\
\text { 2b. Console in a robotic CCY } \\
\text { 3c. Dry laboratory robotic } \mathrm{HJ}\end{array}$ & $\begin{array}{l}\text { 1a. Mock patients / orals } \\
\text { 1b. EMO } \\
\text { 2a. Tutor / self assess } \\
\text { 2b. Video analysis } \\
\text { 3c. CUSUM learning curve }\end{array}$ \\
\hline Biliary 2 & $\begin{array}{l}\text { 1. Follow-up of patients after } \\
\text { complicated robotic biliary surgery } \\
\text { 2. Perform complex robotic biliary } \\
\text { operations }\end{array}$ & $\begin{array}{l}\text { 1a. Shadow office hours } \\
\text { 1b. PBL } \\
\text { 2a. Assist in OR, } \\
\text { bedside } \\
\text { 2b. Perform in OR, } \\
\text { console }\end{array}$ & $\begin{array}{l}\text { 1a. Follow-up complicated biliary patients } \\
\text { 1b. Planning of a redo biliary procedure } \\
\text { 2a. Console in a robotic } \mathrm{HJ},<50 \% \\
\text { 2b. Console in a robotic } \mathrm{HJ},>50 \%\end{array}$ & $\begin{array}{l}\text { 1a. Mock patients / orals } \\
\text { 1b. EMO } \\
\text { 2a. Tutor / self assess } \\
\text { 2b. Video analysis }\end{array}$ \\
\hline Pancreas 1 & $\begin{array}{l}\text { 1. Follow-up of patients after robotic } \\
\text { pancreas surgery } \\
\text { 2. Perform simple robotic pancreas } \\
\text { operations }\end{array}$ & $\begin{array}{l}\text { 1a. Shadow office hours } \\
\text { 1b. PBL } \\
\text { 2a. Assist in OR } \\
\text { 2b. Perform in OR } \\
\text { 2c. Simulation laboratory }\end{array}$ & $\begin{array}{l}\text { 1a. Follow-up robotic débridement patients } \\
\text { 1b. Planning of a robotic débridement } \\
\text { 2a. Bedside in a robotic débridement } \\
\text { 2b. Console in a robotic débridement } \\
\text { 2c. Dry laboratory construction of robotic PJ }\end{array}$ & $\begin{array}{l}\text { 1a. Mock patients / orals } \\
\text { 1b. EMQ } \\
\text { 1a. Tutor / self assess } \\
\text { 2b. Video analysis } \\
\text { 3c. CUSUM learning curve }\end{array}$ \\
\hline Pancreas 2 & $\begin{array}{l}\text { 1. Follow-up of patients after } \\
\text { complicated robotic pancreas surgery } \\
\text { 2. Perform complex robotic pancreas } \\
\text { operations }\end{array}$ & $\begin{array}{l}\text { 1a. Shadow office hours } \\
\text { 1b. PBL } \\
\text { 2a. Assist in OR, } \\
\text { bedside } \\
\text { 2b. Perform in OR, } \\
\text { console }\end{array}$ & $\begin{array}{l}\text { 1a. Follow-up complicated PPPD patients } \\
\text { 1b. Planning of a redo robotic débridement } \\
\text { 2a. Console in a robotic PPPD, }<50 \% \\
\text { 2b. Console in a robotic PPPD, }>50 \%\end{array}$ & $\begin{array}{l}\text { 1a. Mock patients / orals } \\
\text { 1b. EMO } \\
\text { 2a. Tutor / self assess } \\
\text { 2b. Video analysis }\end{array}$ \\
\hline Liver 1 & $\begin{array}{l}\text { 1. Follow-up of patients after robotic } \\
\text { liver surgery } \\
\text { 2. Perform simple robotic hepatic } \\
\text { operations }\end{array}$ & $\begin{array}{l}\text { 1a. Shadow office hours } \\
\text { 1b. PBL } \\
\text { 2a. Assist in OR } \\
\text { 2b. Perform in OR } \\
\text { 2c. Simulation laboratory }\end{array}$ & $\begin{array}{l}\text { 1a. Follow-up robotic LL rsxn patients } \\
\text { 1b. Planning of a proposed robotic rsxn } \\
\text { 2a. Bedside in a robotic LL rsxn } \\
\text { 2b. Console in a robotic LL rsxn } \\
\text { 2c. Dry laboratory robotic rsxn of an actual } \\
\text { 3D-printed liver }\end{array}$ & $\begin{array}{l}\text { 1a. Mock patients / orals } \\
\text { 1b. EMO } \\
\text { 2a. Tutor / Self assess } \\
\text { 2b. Video analysis } \\
\text { 2c. CUSUM learning curve }\end{array}$ \\
\hline Liver 2 & $\begin{array}{l}\text { 1. Follow-up of patients after } \\
\text { complicated robotic liver surgery } \\
\text { 2. Perform complex robotic hepatic } \\
\text { operations }\end{array}$ & $\begin{array}{l}\text { 1a. Shadow office hours } \\
\text { 1b. PBL } \\
\text { 2a. Assist in OR, } \\
\text { bedside } \\
\text { 2b. Perform in OR, } \\
\text { console }\end{array}$ & $\begin{array}{l}\text { 1a. Follow-up complicated rsxn patients } \\
\text { 1b. Planning of a redo rsxn } \\
\text { 2a. Console in a robotic } \mathrm{R} \text { rsxn, }<50 \% \\
\text { 2b. Console in a robotic } \mathrm{R} \text { rsxn, }>50 \%\end{array}$ & $\begin{array}{l}\text { 1a. Mock patients / orals } \\
\text { 1b. EMO } \\
\text { 2a. Tutor / self assess } \\
\text { 2b. Video analysis }\end{array}$ \\
\hline Biliary 3 & $\begin{array}{l}\text { 1. Follow-up of patients after } \\
\text { complicated robotic biliary surgery } \\
\text { 2. Perform complex robotic biliary } \\
\text { operations }\end{array}$ & $\begin{array}{l}\text { 1a. Shadow office hours } \\
\text { 1b. PBL } \\
\text { 2a. Assist in OR, } \\
\text { bedside } \\
\text { 2b. Perform in OR, } \\
\text { console }\end{array}$ & $\begin{array}{l}\text { 1a. Follow-up complicated biliary patients } \\
\text { 1b. Planning of a redo biliary procedure } \\
\text { 2a. Console in a robotic } \mathrm{HJ},<50 \% \\
\text { 2b. Console in a robotic } \mathrm{HJ},>50 \%\end{array}$ & $\begin{array}{l}\text { 1a. Mock patients / orals } \\
\text { 1b. EMQ } \\
\text { 2a. Tutor / self assess } \\
\text { 2b. Video analysis }\end{array}$ \\
\hline Pancreas 3 & $\begin{array}{l}\text { 1. Follow-up of patients after } \\
\text { complicated robotic pancreas surgery } \\
\text { 2. Perform complex robotic pancreas } \\
\text { operations }\end{array}$ & $\begin{array}{c}\text { 1a. Shadow office hours } \\
\text { 1b. PBL } \\
\text { 2a. Assist in OR, } \\
\text { bedside } \\
\text { 2b. Perform in OR, } \\
\text { console }\end{array}$ & $\begin{array}{l}\text { 1a. Follow-up complicated PPPD patients } \\
\text { 1b. Planning of a redo robotic débridement } \\
\text { 2a. Console in a robotic PPPD, }<50 \% \\
\text { 2b. Console in a robotic PPPD, }>50 \%\end{array}$ & $\begin{array}{l}\text { 1a. Mock patients / orals } \\
\text { 1b. EMQ } \\
\text { 2a. Tutor / self assess } \\
\text { 2b. Video analysis }\end{array}$ \\
\hline
\end{tabular}


Table 2 (part 2 of 2). The HPB robotic surgery fellowship curriculum matrix aligning intended learning outcomes, teaching and learning activities and assessments

\begin{tabular}{|c|c|c|c|c|}
\hline Module & Intended learning outcomes & $\begin{array}{c}\text { Teaching and learning } \\
\text { activities }\end{array}$ & Indicative content & Assessment \\
\hline $\begin{array}{l}\text { HPB robotic } \\
\text { surgery } \\
\text { clinical } \\
\text { research }\end{array}$ & $\begin{array}{l}\text { 1. Describe current status of robotic } \\
\text { HPB surgery clinical research } \\
\text { 2. Explain how and why to choose a } \\
\text { subject for robotic HPB surgery } \\
\text { clinical research } \\
\text { 3. Explain clinical research ethics } \\
\text { 4. Describe methods of clinical } \\
\text { research results dissemination } \\
\text { 5. Design and conduct a clinical } \\
\text { research project }\end{array}$ & $\begin{array}{l}\text { 1. Lecture } \\
\text { 2. Tutorial podcast } \\
\text { 3a. PBL } \\
\text { 3b. Reflective journal } \\
\text { 4. Lecture } \\
\text { 5. Write a retrospective } \\
\text { / prospective cohort } \\
\text { analysis }\end{array}$ & $\begin{array}{l}\text { 1. Designing ergonomic triangles for trocar } \\
\text { placement in robotic HPB surgery } \\
\text { 2. How to address a clinical question with an } \\
\text { evidence-based answer in the robotic HPB } \\
\text { surgery era } \\
\text { 3a. Data manipulation in robotic HPB surgery } \\
\text { 3b. Inner thoughts of a clinical researcher } \\
\text { 4. What to present in a scientific poster in } \\
\text { the robotic HPB era } \\
\text { 5. Oncologic outcomes after robotic PPPD }\end{array}$ & $\begin{array}{l}\text { 1. MCO } \\
\text { 2. Portfolio of } 2 \text { pojects } \\
\text { 3a. EMO } \\
\text { 3b. Self / tutor assess } \\
\text { 4. Prepare } 4 \text { abstracts } \\
\text { 5. Clinical research } \\
\text { projects } \times 2\end{array}$ \\
\hline $\begin{array}{l}\text { HPB robotic } \\
\text { surgery } \\
\text { educational } \\
\text { research }\end{array}$ & $\begin{array}{l}\text { 1. Describe current status of robotic } \\
\text { HPB surgery educational research } \\
\text { 2. Explain how to choose a subject } \\
\text { for educational research in robotic } \\
\text { HPB surgery } \\
\text { 3. Explain educational research in } \\
\text { robotic HPB surgery goals } \\
\text { 4. Design and conduct an educational } \\
\text { research project in HPB surgery }\end{array}$ & $\begin{array}{c}\text { 1. Lecture } \\
\text { 2. Tutorial podcast } \\
\text { 3a. PBL } \\
\text { 3b. Reflective journal } \\
\text { 4. Conduct experiment }\end{array}$ & $\begin{array}{l}\text { 1. Simulation training in robotic HPB surgery } \\
\text { 2. Performing educational research that } \\
\text { matters; improving residents' learning in } \\
\text { robotic HPB surgery } \\
\text { 3a. 3-D printing in robotic HPB surgery } \\
\text { 3b. Inner thoughts of a trainee in robotic } \\
\text { HPB surgery } \\
\text { 4. Video vs CUSUM analysis in construction } \\
\text { of a robotic PJ }\end{array}$ & $\begin{array}{l}\text { 1. MCO } \\
\text { 2. Portfolio of } 1 \text { project } \\
\text { 3a. EMO } \\
\text { 3b. Self / tutor assess } \\
\text { 5. Basic research project } \\
\times 1\end{array}$ \\
\hline $\begin{array}{l}\text { HPB robotic } \\
\text { surgery } \\
\text { authorship }\end{array}$ & $\begin{array}{c}\text { 1. Explain how to structure a } \\
\text { scientific communication for robotic } \\
\text { HPB surgery } \\
\text { 2. Explain what to present on a } \\
\text { scientific communication for robotic } \\
\text { HPB surgery } \\
\text { 3. Explain the ethics of scientific } \\
\text { authorship in the era of robotic HPB } \\
\text { surgery } \\
\text { 4. Participate in a greater authorship } \\
\text { project }\end{array}$ & $\begin{array}{l}\text { 1. Tutorial podcast } \\
\text { 2. Tutorial podcast } \\
\text { 3. Lecture } \\
\text { 4. Write a chapter }\end{array}$ & $\begin{array}{l}\text { 1. Types of medical manuscript relevant to } \\
\text { robotic HPB } \\
\text { 2. Video editing of robotic HPB surgical } \\
\text { procedures } \\
\text { 3. The plague of selective reporting in robotic } \\
\text { HPB surgery } \\
\text { 4. Technical pearls for a robotic PPPD }\end{array}$ & $\begin{array}{l}\text { 1. Mock project } \\
\text { 2. Prepare } 2 \text { videos } \\
\text { 3. MCO } \\
\text { 4. Participate in the writing } \\
\text { of the CMC Atlas of } \mathrm{MI} \\
\text { HPB surgery } \times 2 \text { chapters }\end{array}$ \\
\hline
\end{tabular}
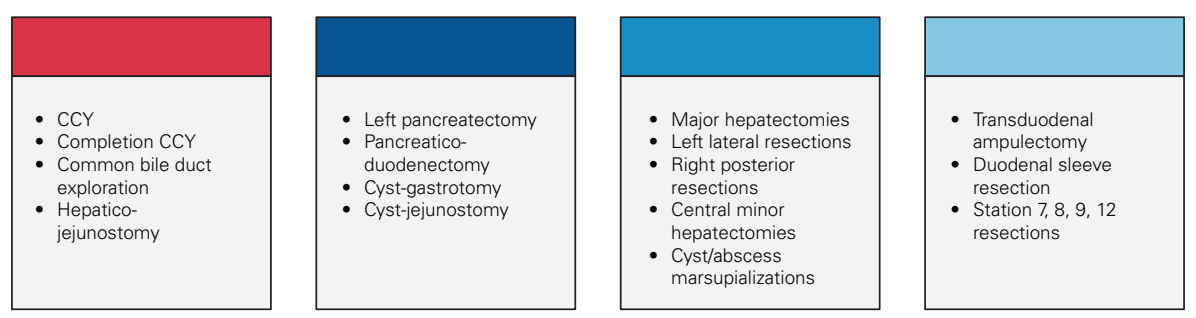

Fig. 1. Index robotic hepato-pancreato-biliary (HPB) surgical procedures performed at Carolinas Medical Center. $\mathrm{CCY}=$ cholecystectomy; $\mathrm{LN}=$ lymph node.

modules, an additional 4 elective modules are required. Vertical integration (between basic and clinical science) is achieved within each module and, depending on caseload, bedside modules ( 3,5 and 7 ) and console modules $\left(4,6,8,9\right.$ and 10) may run in parallel. ${ }^{11}$

This curriculum focuses primarily on incorporation and importance of the cornerstone of intended learning outcomes (ILO), which is competence in performing hepatic, pancreatic and biliary operations. However, other important objectives, such as problem solving, researching, socialization and professionalism, are also incorporated and are considered equally important. These inform fellows of what they should achieve, guide teachers to what they should teach, and clarify assessment processes. All modules are structured to align each ILO with an appropriate teaching/learning activity and a meaningful assessment process.

As our intention is to produce highly specialized HPB surgeons who practise in a tertiary level hospital, teaching and learning activities include substantial operative 


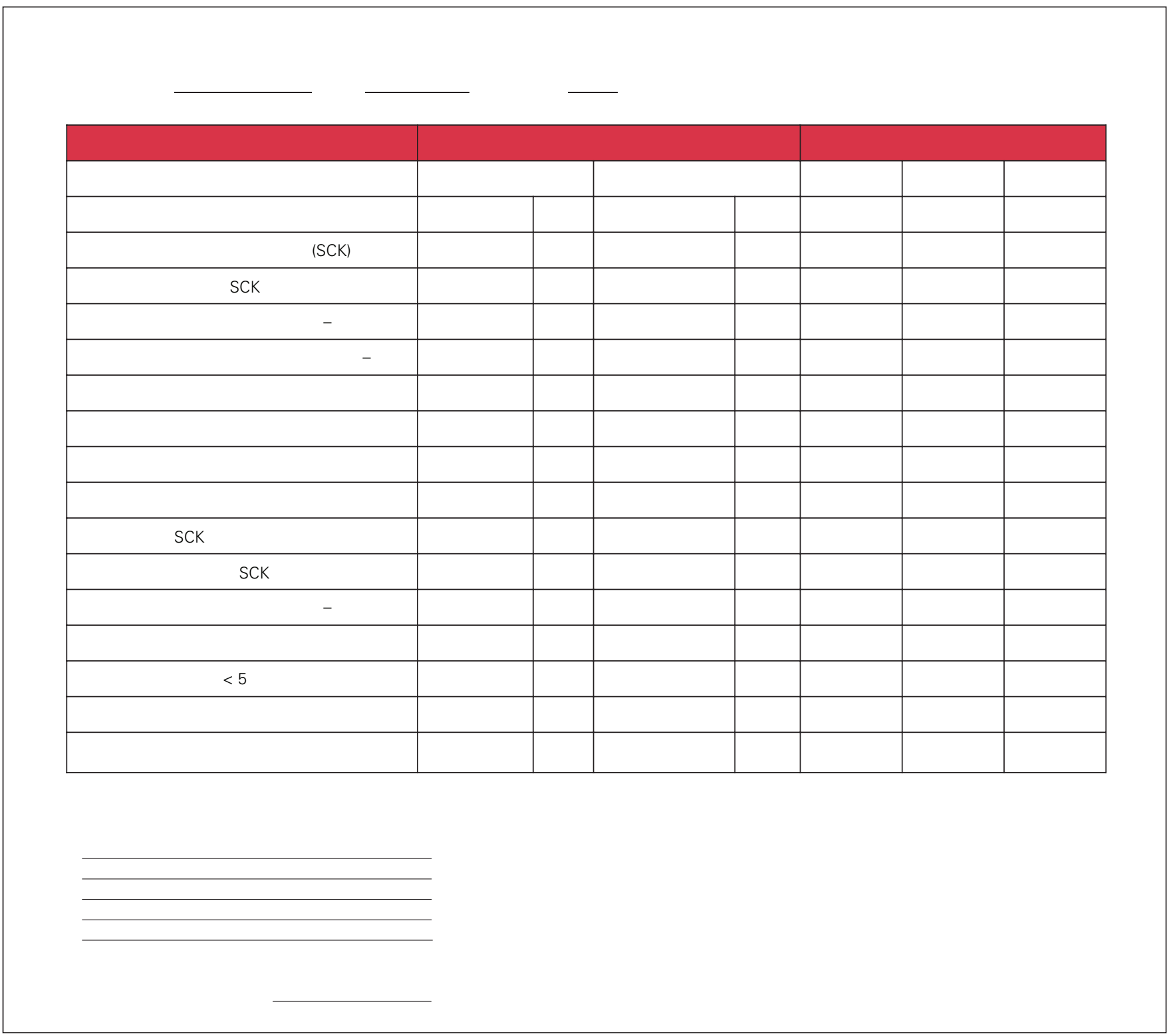

Fig. 2. Template for construction of a cumulative summary (CUSUM) learning curve. ERCP = endoscopic retrograde cholangiopancreatography; N/A = not applicable; $P D=$ pancreatic duct.

exposure and in-house and outpatient treatment formulations. Each module, along with the operative objectives, focuses on appropriately planning and presenting a procedure. As a variety of teaching methods are needed for effective learning, every attempt was made to include more than 1 teaching/learning activity for each desired ILO. This is especially true for the core modules, where $67 \%$ of the ILOs (12 of 18 ) are aligned to more than 1 activity; in the elective modules, $27 \%$ of the ILOs (12 of 44) are aligned to more than 1 activity.

Evaluation is incorporated into the curriculum from the beginning (Figure 2). Many assessment tools are used to encompass data, analysis, judgments and interventions. ${ }^{12}$ The evaluation plan utilizes criteria provided by the major HPB surgery governing bodies. The focus is shifted mainly to the first (learner's satisfaction), second (knowledge acquisition) and third (knowledge implementation) levels of evaluation. This promotes habits of improvement by engaging fellows with challenging clinical cases and via quality-improvement and patient-safety initiatives. It supports formation of professional identity by offering feedback, reflective opportunities and multiaspect assessments. ${ }^{13}$

In concert with the competence-based education idea, the cornerstone ILOs aim to produce highly specialized surgeons who are able to perform simple and complex HPB operations. ${ }^{14}$ To this effect, all core modules contain an ILO described by the phrase "perform an operation." The HPB surgery governing bodies define the key steps of all relevant operative procedures 
and suggest the minimum number of each procedure that should be performed to obtain the competence required to become an independent performer. However, these standards exist only for open classic laparoscopic HPB procedures. The learning curves for performing index robotic HPB surgical procedures are largely unknown and could vary substantially from trainee to trainee. For that reason, we incorporated cumulative summation (CUSUM) to plot the learning curve of each procedure for each individual trainee (Figure 2). ${ }^{15}$ Adopting ILOs assessed by CUSUM analysis might require less time to achieve competence. ${ }^{16}$ In addition, this type of individualized analysis allows identification of specific deficiencies in technical performance of each trainee, leading to suitable interventions for improvement. The curriculum employs both vertical and horizontal integration of disciplines to link theory to practice and to provide a "real" learning environment. The combination of core with various elective modules provides a comprehensive approach to building an HPB robotic surgery personality - an endeavour that requires interprofessional collaboration.

The emergence of robotic surgery into general and specialized surgical practices, including HPB surgery, continues to expand and holds considerable promise for future development. However, residencies and HPB fellowships provide an array of exposure to robotic surgery, resulting in inconsistent technique and ability among HPB surgeons. Often, the only structured training received is through the fundamentals of robotic surgery, designed to deliver only basic knowledge and skill. Thus, the training and exposure required to perform complex procedures is often lacking and, as such, it is important that robotic fellowships be created to allow for an appropriate transition of autonomy and acquisition of a safe and effective skill set. Our curriculum was developed and implemented for this exact purpose. We encourage any individuals who seek to widely incorporate robotics into their practice to seek out or create similar curricula that can provide the appropriate problem-based learning and complex skill acquisition.

Affiliations: From the Division of HPB Surgery, Department of Surgery, Carolinas Medical Center, Atrium Health, Charlotte, North Carolina, USA.

Competing interests: None declared.

Contributors: All authors contributed substantially to the conception, writing and revision of this article and approved the final version for publication.
Content licence: This is an Open Access article distributed in accordance with the terms of the Creative Commons Attribution (CC BYNC-ND 4.0) licence, which permits use, distribution and reproduction in any medium, provided that the original publication is properly cited, the use is noncommercial (i.e., research or educational use), and no modifications or adaptations are made. See: https://creativecommons. org/licenses/by-nc-nd/4.0/

\section{References}

1. Bodner J, Augustin F, Wykypiel H, et al. The da Vinci robotic system for general surgical applications: a critical interim appraisal. Swiss Med Wkly 2005;135:674-8.

2. Hogg ME, Zenati M, Novak S, et al. Grading of surgeon technical performance predicts postoperative pancreatic fistula for pancreaticoduodenectomy independent of patient-related variables. Ann Surg 2016;264:482-91.

3. Birkmeyer JD, Stukel TA, Siewers AE, et al. Surgeon volume and operative mortality in the United States. N Engl 7 Med 2003; 349:2117-27.

4. Farivar BS, Flannagan M, Leitman IM. General surgery residents' perception of robot-assisted procedures during surgical training. 7 Surg Educ 2015;72:235-42.

5. Tom CM, Maciel JD, Korn A, et al. A survey of robotic surgery training curricula in general surgery residency programs: How close are we to a standardized curriculum? Am F Surg 2019;217:256-60.

6. Green CA, Chern H, O'Sullivan PS. Current robotic curricula for surgery residents: a need for additional cognitive and psychomotor focus. Am J Surg 2018;215:277-81.

7. Grant JCE, Jackson G. The Good CPD Guide. Sutton, Surrey: Reed Business Information; 1999.

8. Harden RM. Outcome-based education: the future is today. Med Teach 2007;29:625-9.

9. Nicol D. Research on Learning and Higher Education Teaching. UCoSDA Briefing Paper 45. Sheffield: Universities and Colleges Staff Development Agency; 1997.

10. Fish DC. Continuing medical education: developing a curricula for practice. Maidenhead: Open University Press; 2005.

11. Dornan T, Littlewood S, Margolis SA, et al. How can experience in clinical and community settings contribute to early medical education? A BEME systematic review. Med Teach 2006;28:3-18.

12. Owen J, Grealish L. Clinical education delivery-a collaborative, shared governance model provides a framework for planning, implementation and evaluation. Collegian 2006;13:15-21.

13. Hodges BD, Ginsburg S, Cruess R, et al. Assessment of professionalism: recommendations from the Ottawa 2010 Conference. Med Teach 2011;33:354-63.

14. Harden RM, Davis MH, Crosby JR. The new Dundee medical curriculum: a whole that is greater than the sum of the parts. Med Educ 1997;31:264-71.

15. Grunkemeier GL, Wu YX, Furnary AP. Cumulative sum techniques for assessing surgical results. Ann Thorac Surg 2003;76:663-7.

16. Long DM. Competency-based residency training: the next advance in graduate medical education. Acad Med 2000;75:1178-83. 